\title{
Daniel Callaghan Conservative Party Education Policies, 1976-1997: The Influence of Politics and Personality.
}

Brighton: Sussex Academic Press, 2006. 234 pp.

\section{John Allison}

The analysis of education policy is an exciting study for the historian of education, and even more so for teachers. Submerged in a whirlpool of curriculum, parental expectations, and the day-to-day challenges of running a classroom, teachers rarely have the opportunity to examine what their headmasters and political leaders are planning for them. Daniel Callaghan is one teacher who has looked beyond the classroom and his local school. In his recent work, Conservative Party Education Policies, 1976-1997: The Influence of Politics and Personality, Callaghan masterfully handles the question of Conservative education policy in Britain during the Thatcher era.

The work starts with a chronological analysis of Conservative Party education policy and the development of the British ministry, the national Department of Education and Science (DES). This development takes place under a series of ministers of greater and lesser lustre. In this book, the author makes his central focus the issue of the personality and the role that personality can play in the development of education policy.

Callaghan also introduces the concepts of irregulars, regulars and politicos to categorize personalities. These three groups form the pillars of power that have an influence on the development of education policy. In Callaghan's view, the irregulars are those individuals, bodies and institutions that make their lives on the periphery of the political mainstream. Specifically, irregulars are 'think tanks,' pressure groups, and advisors. (In the world of Bill Clinton's America, former Clinton advisor and consultant Dick Morris would be the classic example of an irregular.) Callaghan notes that "few accounts acknowledge their existence (p.3)." With the changing tides of politics, however, some of the irregulars drift into the camp of the regulars. Regulars are professionals working in a particular policy field. They include officials at the ministry level, administrators and members of "quangos." (The latter is a new term the reviewer has encountered, signifying QUAsi Non-Governmental Organisation, QUasi-Autonomous 
Non-Governmental Organisation, and QUasi-Autonomous National Government Organisation) (p.4). Similarly, Her Majesty's Inspectors (HMI) and the inspectors from the Office of Standards in Education (Ofsted) are also regulars. These officials are roughly analogous to directors of education and superintendents in Canada. Lastly, there are politicos. These individuals are the political office holders, the ministers, the junior ministers, and ultimately, the Prime Minister.

Callaghan notes the early efforts of Margaret Thatcher as supporting the status quo in education when she was Secretary of State in the 1970s, and states that when she became Prime Minister, her ministers were given scant time to show their talents. Here Callaghan wishes to explore the question of personality in all its facets. The nature of leadership (or lack thereof) is described by the author, and the degree of complementarity of views between the Secretary of State for Education, Number 10 Downing Street and the British Prime Minister is well laid out. Mark Carlisle is the first Secretary of State for Education whose contributions are detailed, followed quickly by Sir Keith Joseph. Analytical attention is given to the minutiae of the relationships between these education secretaries and their deputies. The number of secretaries of education for this period speaks volumes about the difficulties these office-holders had in government. No fewer than seven secretaries held the office in this period.

With the appearance of the relatively young Kenneth Baker on the scene as the new Secretary of State for Education in May 1986, a gust of fresh air flowed through the Department. He saw many things that could be changed and updated. In particular he wished to revisit the issue of vouchers for schooling. More significantly he also advocated for the priorities he felt necessary for the continuance of education according to his personal vision.

However, once again politics intervened in the late 1980s. Subsequently, Kenneth Baker was replaced in July 1989 by John MacGregor. MacGregor was unable to grasp that schooling and education in Britain is very political; an odd misapprehension for a minister of the crown. His ability to talk to the stakeholders in the education system made him appear to have sold out to entrenched educational interests, and for this minister such an appearance was a definite disadvantage.

The intervention of Kenneth Clarke brought a period of relative direction back to the office. The changing political landscape of Britain also started to play a role. In 1990, John Major became the Prime Minister of the United Kingdom. Subsequent to his elevation to the office, Major's new Minister of Education was John Patten, serving from May 1992 through July 1994. The final actor in this group was Gillian Shephard. She was the Secretary of State for Education from July 1994 to April 1997. Gillian was an old hand from John Major's constituency; as Callaghan describes her, a member of the "East Anglia Mafia." Callaghan outlines how Shephard ended up getting into numerous arguments and discussions with the Prime Minister and the education policy of Britain suffered because of this. The book ends with the closure of the Major period and the rise of Tony Blair and the Labour Party in the 1997 election.

One aspect of the book that is not readily comprehensible to the international reader is the choice of cartoon graphic on the dust jacket. The graphic shows Secretary Mark Carlisle in an empty cabinet room. Since Carlisle served a very short tenure as Education 
Minister, a more recognizable figure might be a better choice for the dust jacket. Perhaps a collage of figures including Margaret Thatcher and John Major would be even better.

Callaghan does a good job of defining his terms and letting the reader know what the difference is between the DES and the TES (the Department of Education and Science and the Times Educational Supplement). He also provides a well developed dramatis personae at the beginning of the book which proves useful as the number of personalities in this work becomes very extensive. This tool may be particularly important for international readers who may have a limited view of British educational politics.

The typology that Callaghan creates is relatively straightforward. His examination shows how various members of each of the different groups may slide from one group to another. This gives a sense of fluidity to the entire enterprise of leading and administering the school system in Britain.

There are no ultimate villains and no great heroes in this book. Rather, the book articulates the tragedy of the modern policy-making machine, showing how it grinds on regardless of the political players. The players are like sparks in the diffuse light of the great government locomotive which in turn is continually being driven by the changing society all around. Despite the ongoing challenge of capturing and articulating everchanging times, this is a good overview of educational politics and policy making in modern Britain. 
108 Historical Studies in Education/Revue d'histoire de l'éducation 